\title{
Psammomatous Meningioma
}

National Cancer Institute

\section{Source}

National Cancer Institute. Psammomatous Meningioma. NCI Thesaurus. Code C4331.

A WHO grade I meningioma characterized by the presence of psammoma bodies that predominate over the meningeal cells. 